\title{
Astyanax goyanensis (Miranda-Ribeiro, 1944), new combination and Astyanax courensis, new species (Ostariophysi: Characiformes): two Characidae from the upper rio Tocantins basin, Central Brazil
}

\author{
Vinicius A. Bertaco ${ }^{1}$, Fernando R. Carvalho ${ }^{1}$ and Fernando C. Jerep ${ }^{2}$
}

Astyanax goyanensis (Miranda-Ribeiro, 1944), new combination, is redescribed based on the type series and topotypes, and A. courensis, new species, is herein described. Both species were collected in the rio dos Couros basin, upper rio Tocantins basin, Chapada dos Veadeiros, Goiás State, Brazil. These species possess the characters and general body morphology of the species of the Astyanax scabripinnis species complex. The new combination of Astyanax goyanensis is supported by the absence of characters that define Astyanacinus. Astyanax goyanensis and A. courensis differ from their congeners by meristic and morphometric characters, and color pattern. Astyanax goyanensis has only seven pelvic-fin rays, an uncommon character in the species of this genus, and A. courensis possesses only three or four scale rows below the lateral-line, fewer than typical of the genus.

Astyanax goyanensis (Miranda-Ribeiro, 1944), nova combinação, é redescrita com base na série-tipo e topótipos, e A. courensis, espécie nova, é descrita. Ambas espécies foram coletadas na bacia do rio dos Couros, bacia do alto rio Tocantins, Chapada dos Veadeiros, Goiás, Brasil. Estes táxons possuem os caracteres e morfologia do corpo das espécies do complexo Astyanax scabripinnis. A transferência e nova combinação de Astyanax goyanensis devem-se a ausência de caracteres que definem Astyanacinus. Astyanax goyanensis e A. courensis diferem das congêneres por caracteres merísticos, morfométricos e padrão de colorido. Astyanax goyanensis possui apenas sete raios na nadadeira pélvica, caráter incomum nas espécies do gênero, e A. courensis possui apenas três ou quatro séries de escamas abaixo da linha lateral, menos do que típico do gênero.

Key words: Neotropical fish, Astyanacinus, Astyanax scabripinnis species complex, Chapada dos Veadeiros.

\section{Introduction}

The genus Astyanax Baird \& Girard is one of the most speciose assemblages of characiform fishes, composed of almost thirteen dozen of valid species and distributed from southern United States to central Argentina (Lima et al., 2003; Marinho \& Lima, 2009; Eschmeyer \& Fricke, 2010). The nominal species currently assigned to Astyanax probably do not represent a monophyletic entity (Weitzman \& Malabarba, 1998; Vari \& Castro, 2007). The genus is currently defined by a combination of characters proposed by Eigenmann (1921, 1927), as two rows of premaxillary teeth, five teeth in the inner premaxillary series, lateral line complete, adipose fin present, and caudal fin naked. Recently, Mirande (2009) included the genus in an "Astyanax clade" based on the analysis of just some Astyanax species, including the type species of the genus, Astyanax argentatus Baird \& Girard [ $=$ A. mexicanus (De Filippi), according to Lima et al., 2003], along with other genera listed among incertae sedis characids by Lima et al. (2003). In his morphology based phylogenetic hypothesis, Mirande (2009) found Astyanax as a non-monophyletic genus, a fact posteriorly supported by molecular data by Javonillo et al. (2010).

Astyanacinus was proposed by Eigenmann (1907:769) by differing from other characids mainly by "premaxillary with two series of teeth, snout and maxillary forming more than half the length of the head, lateral line complete, maxillary with about six teeth, maxillary-premaxillary border without a

\footnotetext{
${ }^{1}$ Universidade Federal do Rio Grande do Sul, Instituto de Biociências, Departamento de Zoologia, Laboratório de Ictiologia. Av. Bento Gonçalves, 9500, 91501-970 Porto Alegre, RS, Brazil.vbertaco@gmail.com, frcarvalho2004@yahoo.com.br

${ }^{2}$ Setor de Ictiologia, Museu de Ciências e Tecnologia, Pontifícia Universidade Católica do Rio Grande do Sul. Av. Ipiranga 6681, Caixa

Postal 1491, 90619-900 Porto Alegre, RS, Brazil. fjerep@yahoo.com.br
} 
distinct angle". Astyanacinus is composed of four species: A. goyanensis Miranda-Ribeiro (upper rio Tocantins basin), A. moorii (Boulenger) (upper rio Paraguay basin), $A$. multidens Pearson (upper rio Madeira basin), and A. platensis Messner (rio La Plata basin) (Eschmeyer \& Fricke, 2010). The systematic placement of the genus is still uncertain, but according to Calcagnotto et al. (2005) hypothesis of Characiformes phylogeny, Astyanacinus is related to several incertae sedis genera of Characidae: Astyanax, Inpaichthys Géry \& Junk, Hemigrammus Gill, Hyphessobrycon Durbin, and Moenkhausia Eigenmann. Javonillo et al. (2010) also presented a hypothesis of relationship for the major lineages of Characidae based on molecular data. In their parsimony analysis Astyanacinus forms a monophyletic lineage for two unidentified species, being more related to Ctenobrycon and Inpaichthys than to any Astyanax species (A. mexicanus and A. cremnobates).

Astyanacinus goyanensis was described by MirandaRibeiro (1944) based on eight specimens from "rio do Couro, Veadeiros, estado de Goiaz [sic]". The original description is very poor, and some features presented are incomplete, not allowing the recognition of the species from other Astyanax. The author did not explain the reasons for describing the species as Astyanacinus, but might have employed the high number of maxillary teeth (five) and the maxillary size (about half-length of head); two characters used by Eigenmann (1907) to defined that genus but only found in the holotype.

In recent expeditions to tributaries from the upper rio Tocantins basin in the Chapada dos Veadeiros, including the rio dos Couros, new topotypes of Astyanacinus goyanensis were collected with a sympatric new species of Astyanax that is describe herein. The analysis of these specimens and the type series of Astyanacinus goyanensis allowed us to redescribed it in Astyanax according to Eigenmann's definition. These species also fit the definition of the Astyanax scabripinnis species complex proposed by Bertaco \& Lucena (2006), as body deepest and heaviest in area proximate to middle of pectoral fins, head heavy, snout short, body depth smaller than $41 \%$ of SL (usually $30-33 \%$ of SL), lower number of branched anal-fin rays (13-21, usually 17-18, rarely 22-23), presence of one or two humeral spots, and a dark, midlateral body stripe extending to the tip of the middle caudal-fin rays; and they are the first representatives of the group to inhabit the Amazon basin.

\section{Material and Methods}

Counts were taken as described by Fink \& Weitzman (1974), with exception of the number of scale rows below the lateral line which were counted from the scale row ventral to lateral line to the scale row nearest to the origin of first pelvicfin ray. Counts of vertebrae, supraneurals, gill-rakers on the first arch, teeth, and procurrent caudal-fin rays were taken from cleared and stained specimens (c\&s) prepared according to Taylor \& van Dyke (1985). Maxillary tooth counts were also taken from alcohol preserved specimens. Vertebral counts included the four vertebrae of the Weberian apparatus, and the terminal centrum was counted as a single element. Lower and upper jaws of c\&s specimens were prepared for SEM (scanning electronic microscopy) by drying in acetone followed by gold metallization.

Measurements were taken point to point with a caliper on the left side of specimens whenever possible. Measurements are expressed as percents of standard length (SL) except for subunits of the head, which are recorded as percents of head length (HL).

The specimens examined are deposited in the Natural History Museum, London (BMNH), Museu de Ciências e Tecnologia, Pontifícia Universidade Católica do Rio Grande do Sul, Porto Alegre (MCP), Museo Nacional de Historia Natural y Antropologia, Montevideo (MHNM), Museu Nacional, Rio de Janeiro (MNRJ), Departamento de Zoologia, Universidade Federal do Rio Grande do Sul, Porto Alegre (UFRGS), and National Museum of Natural History, Smithsonian Institution, Washington D.C. (USNM).

\section{Astyanax goyanensis (Miranda-Ribeiro, 1944), new combination \\ Figs. 1-2}

Astyanacinus goyanensis Miranda-Ribeiro, 1944:1-2 (original description, type-locality: "Rio do Couro, Veadeiros, estado de Goiaz"; picture of holotype). -Fowler, 1948:34 (distribution). -Lima et al., 2003:108 (maximum length and distribution). -Lima et al., 2007:44 (type-locality and distribution).

Material examined. MNRJ 4129, holotype, female, $82.2 \mathrm{~mm} \mathrm{SL}$, rio dos Couros, Chapada dos Veadeiros, Goiás State, Brazil, 1929, R. Pfrimmer. MNRJ 2843, paratypes, 5 of 7, 59.4-84.8 mm SL, collected with the holotype. MCP 44402, topotypes, 20, 26.9-63.9 mm SL, UFRGS 11291, 80, $5 \mathrm{c} \& \mathrm{~s}$, topotypes, 18.5-79.9 mm SL, small tributary of rio dos Couros at Parque Portal da Chapada, affluent of rio Tocantinzinho, upper rio Tocantins basin, $1135 \mathrm{~m}$ a.s.l, Alto Paraíso de Goiás, Goiás State, Brazil, 14¹0'13”'S 47³6’35”W, 10 Sep 2009 , V. A. Bertaco, F. R. Carvalho \& G. Frainer.

Additional material. Goiás State, Brazil, upper rio Tocantins basin, rio dos Couros basin. MCP 23937, 6, 22.1-61.5 mm SL, córrego Capão da Guabiroba tributary of rio dos Couros, Alto Paraíso de Goiás, 1407'43'S 47³8'27'W, 4 Aug 1996, W. R. Koch, P. Milani \& K. M. Grosser. UFRGS 9905, 19, 27.8-55.6 mm SL, córrego Rita Maria between Cavalcante and Minaçú, rio Paranã basin, Cavalcante, $13^{\circ} 45^{\prime} 16^{\prime \prime}$ S 47 $27^{\prime} 18^{\prime \prime}$ 'W 25 May 2008, F. C. Jerep \& T. P. Carvalho. UFRGS 9935, 31, 2 c\&s, 17.1-50.2 mm SL, córrego on road GO239 between Alto Paraíso de Goiás and Parque Nacional da Chapada dos Veadeiros, Alto Paraíso de Goiás, 1408'24”S 47³9'36"W, 25 May 2008, F. C. Jerep \& T. P. Carvalho. UFRGS 9960, 12, 22.8 $82.4 \mathrm{~mm}$ SL, rio das Cobras between Alto Paraíso de Goiás and Parque Nacional da Chapada dos Veadeiros, 1409'39'S 4737'55'W, 25 May 2008, F. C. Jerep \& T. P. Carvalho.

Diagnosis. Astyanax goyanensis belongs to the $A$. scabripinnis species complex and is distinguished from all 


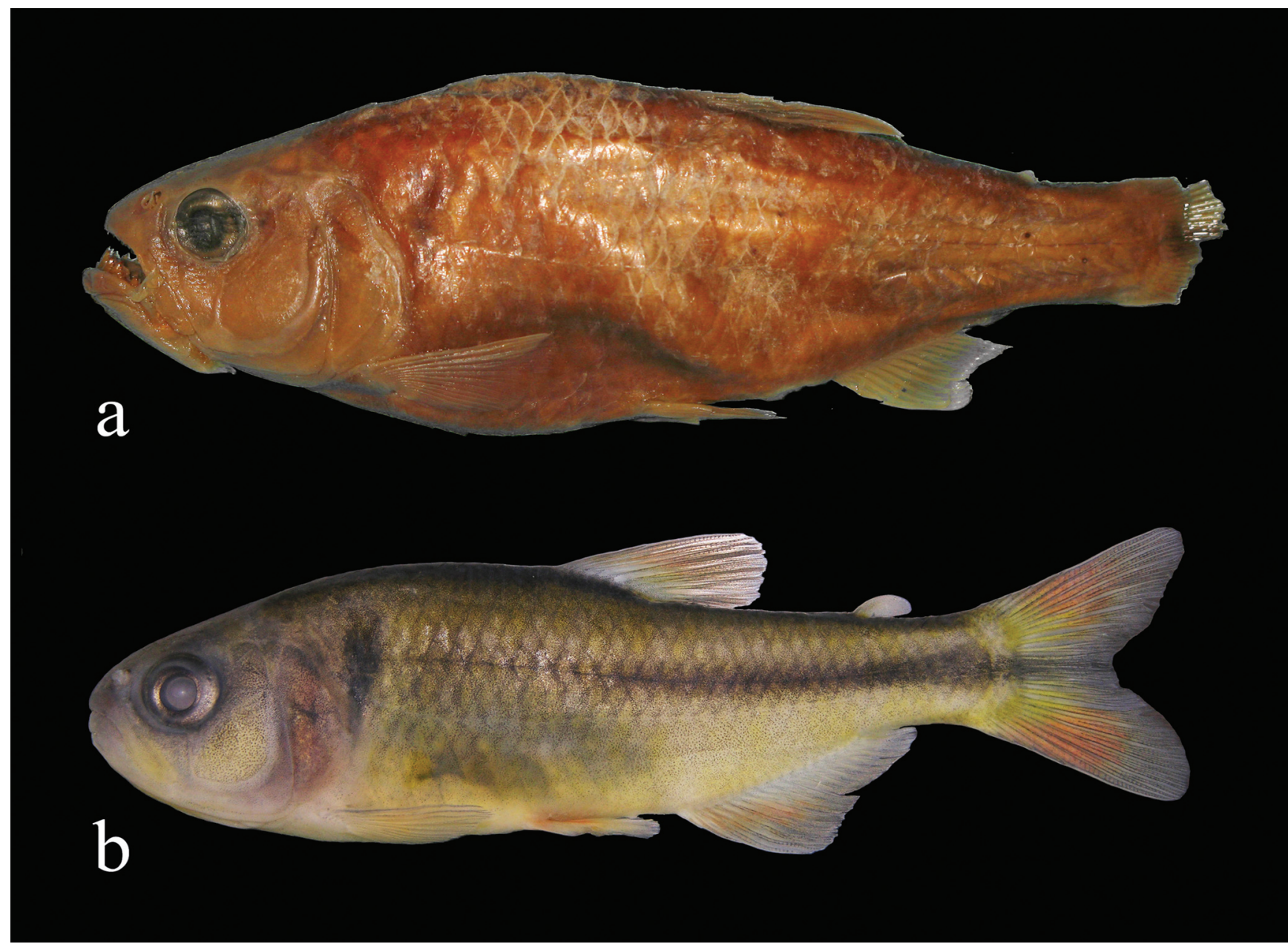

Fig. 1. Astyanax goyanensis. (a) MNRJ 4129, holotype, female, $89.2 \mathrm{~mm} \mathrm{SL}$; rio dos Couros, Chapada dos Veadeiros, Goiás State, Brazil (anal-fin incomplete); (b) UFRGS 11291, topotype, male, $56.7 \mathrm{~mm} \mathrm{SL}$; small stream tributary of rio dos Couros at Parque Portal da Chapada, tributary of rio Tocantinzinho, upper rio Tocantins basin, Alto Paraíso de Goiás, Goiás State, Brazil.

species of this complex by the total number of pelvic-fin rays (7 vs. 8), except from A. brachypterygium Bertaco \& Malabarba, A. ita Almirón, Azpelicueta \& Casciotta, and A. obscurus (Hensel), Bertaco \& Lucena (2010). It differs from $A$. brachypterygium by caudal peduncle length $(14.1-18.5 \% \mathrm{SL}$, mean $=16.1$ vs. 11.9-14.4, mean $=13.0$ ), by the number of caudal-peduncle scales (14 vs. 16), and by the number of cusps of the premaxillary inner series and the larger dentary teeth (4-5 vs. 5-7); from $A$. ita by the number of branched anal-fin rays (13-16 vs. 20-24), number of humeral spots ( $2 v s .1)$, and by the orbital diameter $(20.2-33.2 \% \mathrm{HL}$, mean $=27.4 v s$. 38.642.0 , mean $=40.2$ ); and from A. obscurus by the number of maxillary teeth (2-5 vs. 1), number of lateral line scales (35-37, mean $=36 v s .37-39$, mean $=38)$, and by the number of branched anal-fin rays $(13-16$, mean $=14.7 v s .16-21$, mean $=18.3)$. Furthermore, the lower number of the branched anal-fin rays in $A$. goyanensis distinguish it from its congeners of the species complex, except from $A$. brachypterygium, $A$. cremnobates Bertaco \& Malabarba, A. laticeps (Cope), $A$. intermedius Eigenmann, A. jenynsii (Steindachner), $A$. jordanensis Alcaraz, Pavanelli \& Bertaco, A. microschemos
Bertaco \& Lucena, A. totae Haluch \& Abilhoa, and A. varzeae Abilhoa \& Duboc. It differs from most these species by the number of humeral spot (2 vs. 1), except $A$. brachypterygium, A. cremnobates, and $A$. varzeae. From these three species it differs by the number of cups in the premaxillary and dentary teeth (5-7 vs. 3-5), and by the caudal-peduncle length (14.1$18.5 \%$ SL, mean $=16.1$ vs. $11.9-14.4$, mean $=13.0,11.0-14.9$, mean $=13.1,10.5-13.9$, mean $=12.4$, respectively), and additionally from $A$. varzeae by the number of lateral line scales $(35-37$, mean $=36$ vs. $37-42$, mean $=39)$.

Description. Morphometric data summarized in Table 1. Body compressed and elongate; greatest body depth usually immediately anterior to dorsal-fin origin. Dorsal profile of head between vertical through posterior nostril and tip of supraoccipital spine straight or slightly convex. Profile of body convex from tip of supraocciptal spine to base of last dorsalfin ray, and slightly concave from that point to adipose-fin origin. Ventral profile of head convex. Ventral profile of body slightly convex from pectoral-fin insertion to anal-fin origin. Body profile along anal-fin base posterodorsally slanted. 


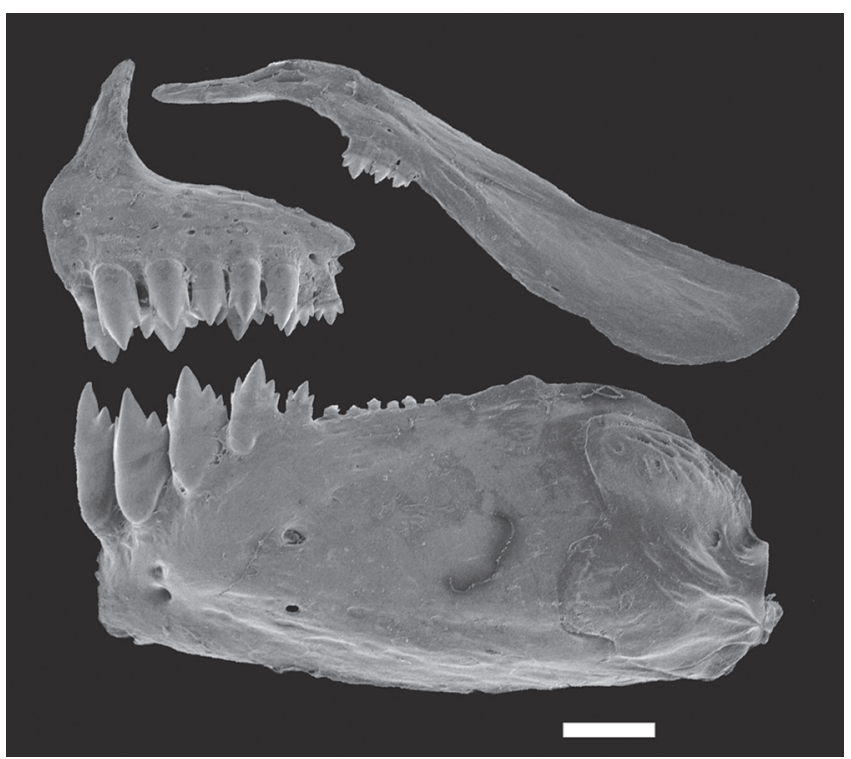

Fig. 2. Astyanax goyanensis, UFRGS 11291, $59.2 \mathrm{~mm}$ SL. Scanning electronic microscopy images of the upper and lower jaws, left side, lateral view. Scale bar $=1 \mathrm{~mm}$.

Caudal peduncle elongate and nearly straight to slightly concave along both dorsal and ventral margins.

Snout rounded from margin of upper lip to vertical through anterior nostrils. Head relatively small (one third of SL). Mouth terminal, lower jaw projecting slightly more than upper jaw. Maxilla extending posteriorly to vertical through anterior half of orbit, slightly curved, and aligned at angle of approximately 45 degrees relative to longitudinal body axis. Maxilla slightly widened anteroposteriorly.

Premaxilla with two tooth rows: outer row with three to five tri- to pentacuspid teeth, central cusp longest. Five teeth in inner premaxillary row; teeth gradually decreasing in length from first towards fourth teeth with last tooth distinctly smaller: teeth with five to seven cusps with central cusp twice as long and broad as other cusps. Maxilla with two to five (five only in the holotype and one paratype) teeth with three to five cusps; central cusp longest. Three to four anteriormost dentary teeth larger, with five or seven cusps, followed by one medium-sized tooth with three to five cusps, and five to seven teeth with one to three cusps. Central cusp in all teeth two to three times as long and broad as other cusps. All cusp tips slightly curved posteriorly towards oral cavity (Fig. 2).

Dorsal-fin rays ii,9 (holotype with ii,8; three paratypes with i,9, seven topotypes with i,9, and ii,8 in two c\&s specimens, $\mathrm{n}=32$ ); first unbranched ray approximately half length of second ray. Distal margin of dorsal fin nearly straight or slightly convex. Dorsal-fin origin anterior at middle of SL. Adipose-fin origin approximately at vertical through insertion of base of last anal-fin ray. Anal-fin rays ii-v, 13-16 (holotype with anal incomplete, 13 , mean $=14.7, n=32$ ). First unbranched ray apparent only in c\&s specimens. Anal-fin profile nearly straight in males, and smoothly concave in females. Anal-fin origin posterior to vertical through base of last dorsal-fin ray. Anal-fin rays of males bearing one pair of small bony hooks along posterolateral border of each segment of lepidotrichia, usually along last unbranched ray to eighth anterior branched rays. Hooks more numerous along second through fifth branched ray, and usually located along posteriormost branch and distal $1 / 2$ to $2 / 3$ of each ray.

Pectoral-fin rays i,10-13 (mean $=12 \cdot 0, n=32)$. Tip of pectoral fin reaching pelvic-fin insertion in males and not reaching that insertion in females. Pelvic-fin rays i,6 $(n=32)$. Pelvic-fin origin slightly anterior to vertical through dorsal-fin origin. Tip of pelvic fin reaching anal-fin origin in males, falling short of that point in females. Caudal fin forked and unscaled, lobes similar in size, with 19 principal rays. Dorsal procurrent rays 11-14, and ventral procurrent rays 10-12 $(n=7)$.

Lateral line complete with 35-37 scales (mean $=36.0, \mathrm{n}=$ 32). Scale rows between dorsal-fin origin and lateral line 6-7 $($ mean $=6.1, \mathrm{n}=32) ; 4-5$ scale rows between lateral line and pelvic-fin origin $($ mean $=4.5, \mathrm{n}=32$ ). Predorsal scales 11-14 $($ mean $=12.5, \mathrm{n}=32)$ usually arranged in regular series. Scale rows around caudal peduncle $14(\mathrm{n}=32)$. Axillary scale on pelvic-fin origin extends posteriorly covering 2-3 scales. Scale sheath along anal-fin base 5-12 scales, in single series, covering base of anteriormost rays $(\mathrm{n}=30)$.

Precaudal vertebrae 17-18; caudal vertebrae 17-18; total vertebrae $35(n=7)$. Supraneurals 5-7 $(n=7)$. Upper branch of gill-rakers 7-8, lower branch 11-12 $(\mathrm{n}=7)$.

Color in alcohol. General body color yellowish-brown. Dark chromatophores scattered on lateral portion of head, more densely concentrated on snout and anterior border of eye. Lateral portion of body with scales bordered with dark pigment, forming slightly reticulate pattern. Body with black, pigmented, midlateral stripe extending from humeral region to base of middle caudal fin; faint dark pigmentation present on middle caudal-fin rays. Midlateral body stripe expanded dorsally and ventrally to caudalfin base, forming small caudal spot. Two humeral spots: anterior spot conspicuous, vertically elongate, with superior portion wider, located over second to fourth vertical series of scales, extending over 2 to 3 horizontal series of scales above lateral line; and inferior portion of spot narrow, and extending over 1 to 2 horizontal series of scales below lateral line; posterior humeral spot diffuse, not ventrally surpassing lateral-line, extending over 2 to 3 horizontal series and 2 to 3 vertical series of scales. Region between spots pale. Fins with dispersed dark chromatophores (Fig. 1b). Specimens retained orange and yellowish pigment on all fins after several days fixation in formalin.

Color in life. The specimens immediately after capture presented overall golden body coloration. Fins yellowish-orange to red. Humeral spots faint black, and midlateral stripe and caudalpeduncle spot less conspicuous than after preservation. Caudalfin middle rays black (Fig. 1b).

Sexual dimorphism. Males of Astyanax goyanensis are easily recognized by the presence of small bony hooks on the anal-fin rays (see Description). Also, males and females differ by anal-fin shape, which is nearly straight in males and concave in females. 
Gill glands (Burns \& Weitzman, 1996) were not found macroscopically on first gill arch in either males or females.

Distribution. Astyanax goyanensis is known from tributaries of the rio dos Couros, affluent of rio Tocantinzinho, and rio Paranã basin, upper rio Tocantins basin, Chapada dos Veadeiros, Goiás, Brazil (Fig. 3).

Ecological notes. The collection locality is around $1135 \mathrm{~m}$ above sea level. The rio dos Couros in that point has moderate riparian vegetation and it is typically between 10 and $15 \mathrm{~m}$ wide, and 1.5 $\mathrm{m}$ deep. Although presenting some rapids, the water is clear. The substrate is constituted by stones, rocks, and some stretches with mud. A natural $10 \mathrm{~m}$ high waterfall named Cachoeira São Bento is located downriver. All topotypes were collected on the stretch downstream from the waterfall in a small stream draining directly into the river (about $100 \mathrm{~m}$ from the channel river). The stream is about $0.8 \mathrm{~m}$ deep and $6 \mathrm{~m}$ wide, has transparent water with moderate vegetation covering the channel (trees and shrubs), and bottom with small stones, submerged logs and roots (Fig. 4b). No other fish species was collected with $A$. goyanensis in the stream. The rio dos Couros has several waterfalls, some with about $100 \mathrm{~m}$ height (Cachoeira de São Vicente and Catarata dos Couros). Stomach contents of five specimens contained fragments of allochthonous insect, fish scales, and vegetal organic matter (leaf parts). The stomachs were not full.

\section{Astyanax courensis, new species Figs. 5-6}

Holotype. UFRGS 11499, $54.2 \mathrm{~mm}$ SL, female, rio dos Couros at Parque Portal da Chapada, tributary of rio Tocantinzinho, upper rio Tocantins basin, $1135 \mathrm{~m}$ a.s.l, Alto Paraíso de Goiás, Goiás State, Brazil, 1409'58”S 47³5'43”W, 10 Sep 2009, V. A. Bertaco, F. R. Carvalho \& G. Frainer.

Paratypes. Alto Paraíso de Goiás, Goiás State, Brazil, upper rio Tocantins basin, rio dos Couros basin. MCP 44403, 20, 26.0-59.2 mm SL, UFRGS 11290, 107, 5 c\&s, 16.6-71.6 mm SL, UFRGS 11295, 5 (ethyl alcohol anhydrous), 23.4-29.5 mm SL, collected with the holotype. MCP 44404, 1, $44.0 \mathrm{~mm} \mathrm{SL}$, córrego Capão da Guabiroba, tributary of rio dos Couros, 1407'43'S 47³8'27'W, 4 Aug 1996, W. R. Koch, P. Milani \& K. M. Grosser. UFRGS 9934, 5, 21.1-36.4 mm SL, córrego on road GO-239 between Alto Paraíso de Goiás and Parque Nacional da Chapada dos Veadeiros, 1408'24"S 47³9'36"W, 25 May 2008, F. C. Jerep \& T. P. Carvalho. UFRGS 11588, 38, 2 c\&s, 18.7-48.2 mm SL, rio das Cobras between Alto Paraíso de Goiás and Parque Nacional da Chapada dos Veadeiros, 1409'39”'S 47³7'55”W, 25 May 2008, F. C. Jerep \& T. P. Carvalho.

Diagnosis. Astyanax courensis belongs to the A. scabripinnis species complex and is distinguished from other species of this complex by the number of scale rows between lateral line and pelvic fin origin (3-4 vs. 5-6), except from $A$. brachypterygium, A. burgerai Zanata \& Camelier, $A$. goyanensis, A. intermedius Eigenmann, A. jenynsii, A.

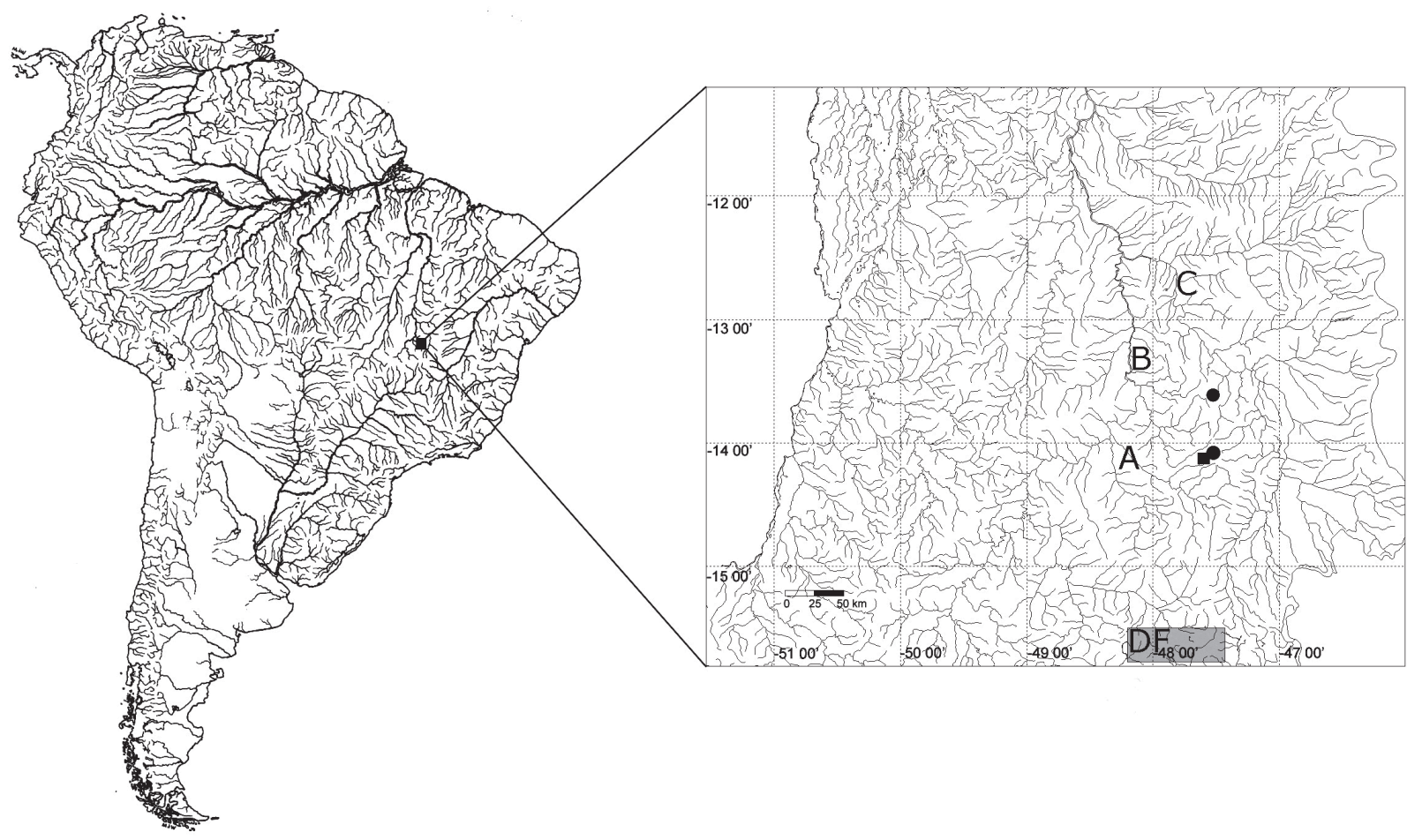

Fig. 3. Distribution of Astyanax goyanensis (circles) and A. courensis, new species (square), on upper rio Tocantins, Alto Paraíso de Goiás, Goiás State, Brazil. A, rio Tocantinzinho; B, rio Tocantins; C, rio Paranã; DF, Distrito Federal. Symbols can represent more than one lot or locality. Base map prepared by Marilyn Weitzman. 


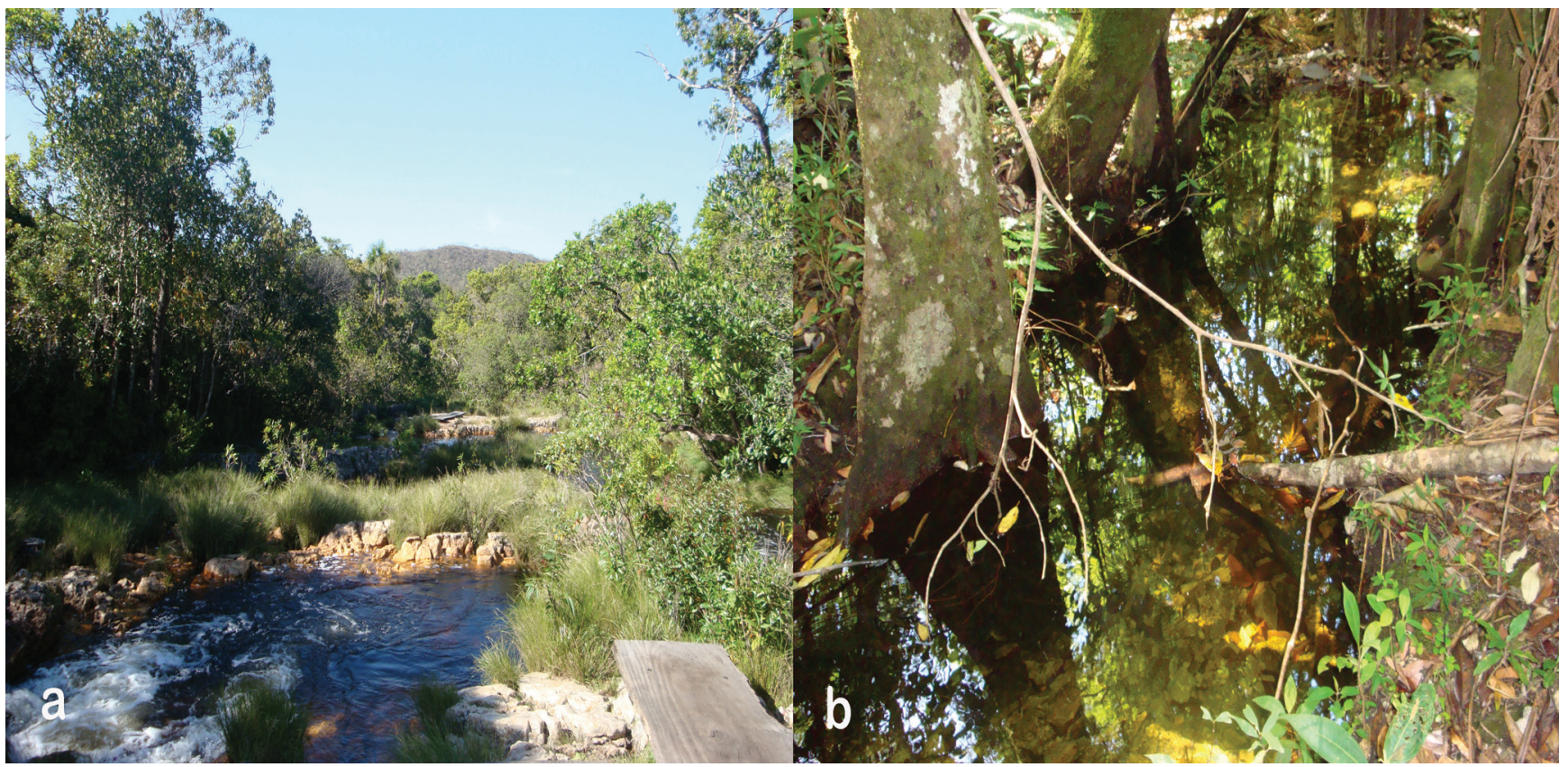

Fig. 4. (a) Rio dos Couros downstream from the Cachoeira São Bento, type-locality of Astyanax courensis, new species; (b) small stream tributary of rio dos Couros at Parque Portal da Chapada, locality of collection of Astyanax goyanensis.

microschemos, $A$. rivularis Lütken, $A$. totae, and $A$. varzeae. It differs from $A$. brachypterygium, $A$. goyanensis, and $A$. totae by head length $(24.9-28.2 \% \mathrm{SL}$, mean $=26.6 \mathrm{vs} .27 .8$ 33.2 , mean $=29.9,27.7-32.3$, mean $=31.6$, and 27.9-32.8, mean $=29.7$, respectively), and by the number of humeral spots $(1$ vs. 2, except in $A$. totae, which has one). It differs from $A$. burgerai and $A$. intermedius by shape of the dentary teeth (abruptly decreasing in size after fourth tooth $v s$. teeth gradually decreasing in size posteriorly), and orbital diameter $(24.9-31.9 \%$ HL, mean $=27.9 v s .34 .6-40.6$, mean $=38.0,32.5$ 47.8 , mean $=39.0$, respectively); from $A$. jenynsii by the number of branched anal-fin rays $(15-17$, mean $=15.8 v s .13-15$, mean $=$ $14)$ and upper jaw length $(40.6-50.0 \%$ HL, mean $=44.9 v s .35 .9-$
39.5 , mean $=37.4)$; from $A$. rivularis by body depth $(27.4$ $33.1 \% \mathrm{SL}$, mean $=30.5 v \mathrm{vs} .35 .0-46.0$, mean $=40.3$ ), and by the number of humeral spots ( 1 vs. 2$)$; from $A$. varzeae by the number of lateral line scales (35-36, mean $=35.4 v s .37-42$, mean $=39)$, caudal-peduncle length $(13.6-16.9 \% \mathrm{SL}$, mean $=$ 15.2 vs. $10.5-13.9$, mean $=12.4)$ and orbital diameter $(24.9-31.9 \%$ HL, mean $=27.9$ vs. 30.9-44.5, mean $=37.9$ ). Furthermore, it differs from A. microschemos and A. totae by the number of maxillary teeth (1 vs. 2-3 and 2-5, respectively). Astyanax courensis differs from only sympatric Astyanax species, $A$. goyanensis, by the number of pelvic-fin rays $(8 \mathrm{vs} .7)$, and number of maxillary teeth $(1 \mathrm{vs.} 2-5)$, and by prepectoral distance $(23.7-27.8 \% \mathrm{SL}$, mean $=26.4 v s .27 .7-32.0$, mean $=30.4)$.

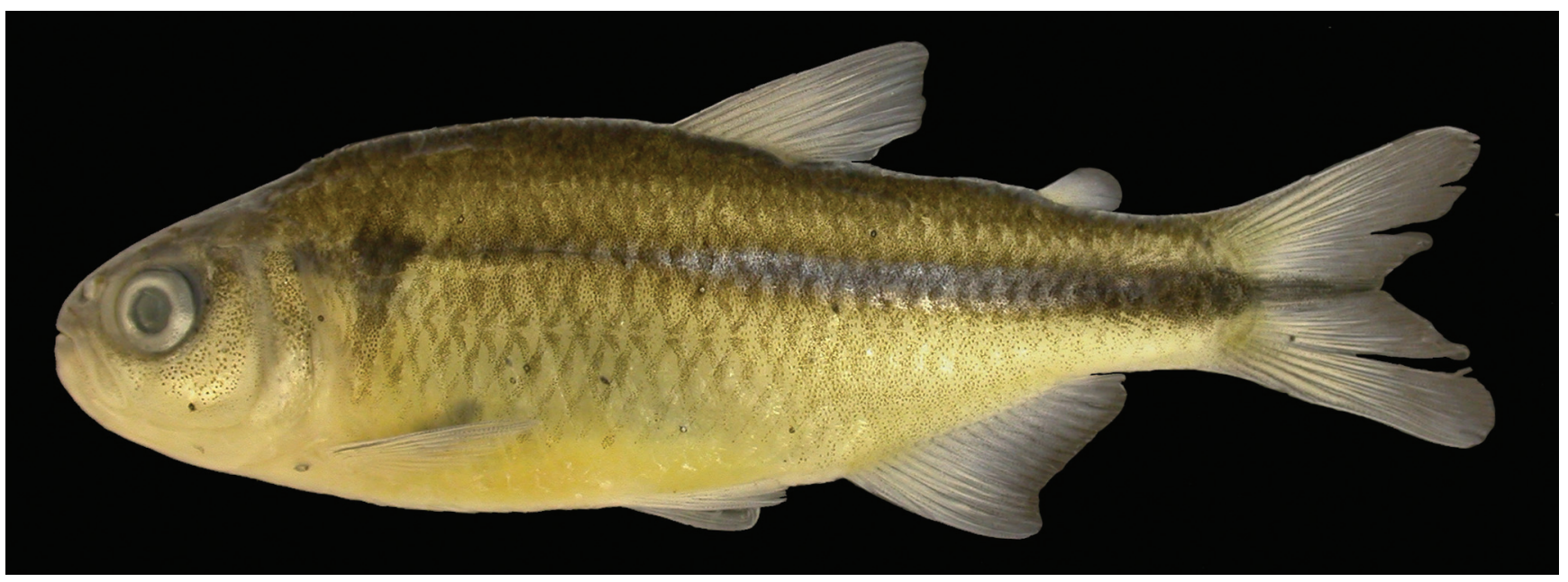

Fig. 5. Astyanax courensis, new species, UFRGS 11499, holotype, female, $54.2 \mathrm{~mm}$ SL; rio dos Couros at Parque Portal da Chapada, tributary of rio Tocantinzinho, upper rio Tocantins basin, Alto Paraíso de Goiás, Goiás State, Brazil. 


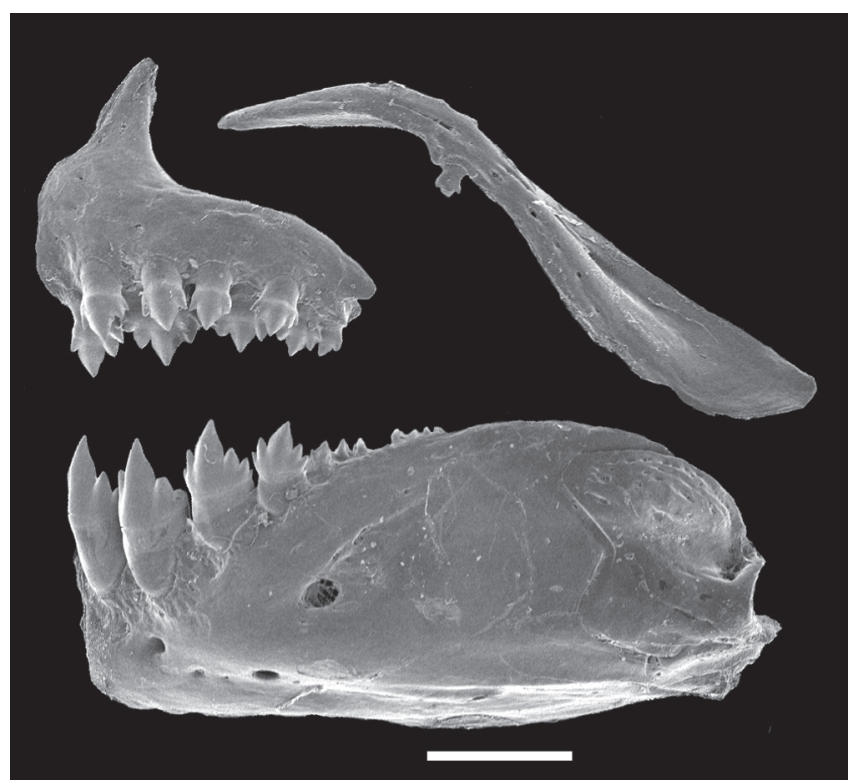

Fig. 6. Astyanax courensis, new species, UFRGS 11290, 45.0 $\mathrm{mm}$ SL. Scanning electronic microscopy images of upper and lower jaws, left side, lateral view. Scale bar $=1 \mathrm{~mm}$.

Description. Morphometric data summarized in Table 1 . Body compressed and elongate; greatest body depth usually immediately anterior to dorsal-fin origin. Dorsal profile of head between vertical through posterior nostril and tip of supraoccipital spine straight or slightly convex. Profile of body convex from tip of supraocciptal spine to base of last dorsal-fin ray, and straight from that point to adipose-fin origin. Ventral profile of head convex. Ventral profile of body slightly convex from pectoral-fin insertion to anal-fin origin. Body profile along anal-fin base posterodorsally slanted. Caudal peduncle elongated, nearly straight to slightly concave along both dorsal and ventral margins.

Snout rounded from margin of upper lip to vertical through anterior nostrils. Head relatively small. Mouth terminal, lower jaw slightly projected over upper jaw. Maxilla extending posteriorly to vertical through anterior half of orbit, slightly curved, and aligned at angle of approximately 45 degrees relative to longitudinal body axis. Maxilla slightly widened anteroposteriorly.

Premaxilla with two tooth rows; outer row with four to six tri- to pentacuspid teeth with central cusp longest. Five teeth in inner premaxillary row; teeth gradually decreasing in length from first towards fourth tooth with last tooth distinctly smaller: teeth with five to seven cusps with central cusp twice as long and broad as other cusps. Maxilla with one tooth (rarely two) with three to five cusps, and central cusp longest. Three to four anteriormost dentary teeth larger, with five or seven cusps, followed by one medium-sized tooth with three to five cusps, and then five to seven teeth with one to three cusps. Central cusp in all teeth two to three times as long and broad as other cusps. All cusp tips slightly curved posteriorly towards oral cavity (Fig. 6).
Dorsal-fin rays ii,9 $(n=30)$; first unbranched ray approximately half length of second ray. Distal margin of dorsal fin nearly straight or slightly convex. Dorsal-fin origin anterior at middle of SL. Adipose-fin origin approximately at vertical through insertion of base of last anal-fin ray. Anal-fin rays iii-v, 15-17 (mean $=15.8, \mathrm{n}=30)$. First unbranched ray normally only apparent in c\&s specimens. Anal-fin profile nearly straight in males, and smoothly concave in females. Anal-fin origin posterior to vertical through base of last dorsal-fin ray. Anal-fin rays of males bearing one pair of small bony hooks along posterolateral border of each segment of lepidotrichia, usually along last unbranched ray to sixth anterior branched ray. Hooks more numerous along second through fourth branched rays, and usually located along posteriormost branch and distal $1 / 2$ to $2 / 3$ of each ray.

Pectoral-fin rays i,10-12 $($ mean $=10.7, \mathrm{n}=30)$. Tip of pectoral fin not reaching the pelvic-fin origin in both sexes. Pelvic-fin rays i,7 $(n=30)$. Pelvic-fin origin slightly anterior to vertical through dorsal-fin origin. Tip of pelvic fin surpassing the urogenital opening in males, and only reaching that point in females. Caudal fin forked and unscaled, lobes similar in size, with 19 principal rays (one specimen with 17). Dorsal procurrent rays 10-13, and ventral procurrent rays 9-11 $(\mathrm{n}=7)$.

Lateral line complete with 35-36 scales (mean $=35.4, \mathrm{n}=$ $30)$. Scale rows between dorsal-fin origin and lateral line 5 $6($ mean $=5.4, \mathrm{n}=30) ; 3-4$ scale rows between lateral line and pelvic-fin origin (mean $=3.9, \mathrm{n}=30$ ). Predorsal scales $11-13$ (mean $=12.2, \mathrm{n}=29)$ usually arranged in regular series. Scale rows around caudal peduncle $14(\mathrm{n}=30)$. Axillary scale on pelvic-fin insertion posteriorly extended covering 1-2 scales. Scale sheath along anal-fin base 5-8 scales, in single series, covering base of anteriormost rays.

Precaudal vertebrae 17-18; caudal vertebrae 17-18; total vertebrae 34-35 $(n=7)$. Supraneurals 5-6 $(n=7)$. Upper branch of gill rakers 6-7, lower branch 11-12 $(n=7)$.

Color in alcohol. General body color yellowish-brown. Dark chromatophores scattered on lateral portion of head, but more densely concentrated on snout and anterior border of eye. Lateral portion of body with scales posteriorly bordered by dark pigment and forming reticulate pattern. Body with black, pigmented, midlateral stripe extending from the upper border of the opercle to the caudal-fin base; dark pigmentation present on middle caudal-fin rays. Midlateral body stripe expanded dorsally and ventrally proximate to caudal-fin base, forming small caudal spot. Humeral spot conspicuous, vertically elongate with superior portion of spot wider, located over second to fourth vertical series of scales and extending over 2 to 3 horizontal series of scales above lateral line; and inferior portion of spot narrower, and extending over 1 to 2 horizontal series of scales below lateral line. Region just posterior to the humeral spot pale in some specimens. Fins with few dispersed dark chromatophores (Fig. 5). Specimens 
Table 1. Morphometric data of holotype (H), paratypes, and non-types of Astyanax goyanensis, and holotype and paratypes of Astyanax courensis, new species, from the rio dos Couros basin, upper rio Tocantins basin, Alto Paraíso de Goiás, Goiás State, Brazil. The range of paratypes and non-types of $A$. goyanensis not includes the holotype, but of $A$. courensis includes.

\begin{tabular}{|c|c|c|c|c|c|c|c|c|c|c|c|}
\hline & \multicolumn{7}{|c|}{ A. goyanensis } & \multirow{2}{*}{\multicolumn{4}{|c|}{$\begin{array}{r}\text { A. courensis } \\
\text { Paratypes }\end{array}$}} \\
\hline & \multicolumn{3}{|r|}{ Paratypes } & \multicolumn{4}{|c|}{ Non-types } & & & & \\
\hline & $\mathrm{H}$ & $\mathrm{N}$ & Range & Mean & $\mathrm{N}$ & Range & Mean & $\mathrm{H}$ & $\mathrm{N}$ & Range & Mean \\
\hline Standard length $(\mathrm{mm})$ & 89.2 & 5 & $59.4-84.8$ & 66.2 & 32 & $44.4-83.8$ & 59.5 & 54.2 & 30 & $33.2-72.3$ & 48.2 \\
\hline \multicolumn{12}{|c|}{ Percents of standard length } \\
\hline Predorsal distance & 52.3 & 5 & $51.7-58.0$ & 55.2 & 32 & $53.1-56.9$ & 55.1 & 55.8 & 30 & $51.3-55.8$ & 54.0 \\
\hline Prepelvic distance & 48.6 & 5 & $49.7-52.9$ & 51.2 & 32 & $49.7-55.4$ & 52.0 & 50.4 & 30 & $47.1-51.3$ & 49.6 \\
\hline Prepectoral distance & 27.7 & 5 & $31.0-32.0$ & 31.4 & 32 & $27.9-32.0$ & 29.5 & 26.4 & 30 & $23.7-27.8$ & 26.4 \\
\hline Preanal distance & 65.2 & 5 & $65.6-73.7$ & 69.1 & 32 & $66.1-71.5$ & 68.4 & 69.1 & 30 & $65.0-70.8$ & 68.2 \\
\hline Depth at dorsal-fin origin & 31.9 & 5 & $31.2-36.6$ & 33.4 & 32 & 29.2-34.9 & 32.9 & 33.1 & 30 & $27.4-33.1$ & 30.5 \\
\hline Caudal-peduncle depth & 10.3 & 5 & $11.3-12.2$ & 11.6 & 32 & $11.3-13.1$ & 12.1 & 12.8 & 30 & $10.9-12.8$ & 11.8 \\
\hline Caudal-peduncle length & - & - & - & - & 32 & $14.1-18.5$ & 16.1 & 16.9 & 30 & $13.2-16.9$ & 15.2 \\
\hline Anal-fin base & - & 5 & $16.3-19.4$ & 17.7 & 32 & $18.4-23.8$ & 20.6 & 20.5 & 30 & $17.9-23.9$ & 20.9 \\
\hline Dorsal-fin length & 19.3 & 5 & $22.8-26.8$ & 25.1 & 32 & $20.9-28.5$ & 24.0 & 23.6 & 30 & $20.7-26.2$ & 23.3 \\
\hline Pelvic-fin length & 15.6 & 5 & $12.0-16.8$ & 14.8 & 32 & $12.5-17.1$ & 14.9 & 15.1 & 30 & $13.5-17.2$ & 15.3 \\
\hline Pectoral-fin length & 18.3 & 5 & $16.7-21.8$ & 19.5 & 32 & $18.1-23.4$ & 20.7 & 20.1 & 30 & -21.7 & 20.2 \\
\hline Head length & 27.7 & 5 & $30.8-32.3$ & 31.6 & 32 & $28.3-31.8$ & 29.5 & 25.7 & 30 & $24.9-28.2$ & 26.6 \\
\hline \multicolumn{12}{|c|}{ Percents of head length } \\
\hline Snout length & 27.5 & 5 & $23.0-27.2$ & 25.2 & 32 & $21.4-27.2$ & 23.6 & 24.7 & 30 & $21.9-27.1$ & 23.7 \\
\hline Upper jaw length & 51.5 & 5 & $47.5-50.0$ & 48.9 & 32 & $43.6-50.9$ & 46.6 & 45.2 & 30 & $40.6-50.0$ & 44.9 \\
\hline Orbital diameter & 27.6 & 5 & $25.2-33.2$ & 29.1 & 32 & $20.2-30.3$ & 25.8 & 26.9 & 30 & 24.9-31.9 & 27.9 \\
\hline Interorbital width & 33.9 & 5 & $30.4-34.5$ & 32.8 & 32 & $27.8-34.7$ & 31.3 & 31.5 & 30 & $26.7-33.0$ & 30.1 \\
\hline
\end{tabular}

retained orange and yellowish pigment on all fins after several days fixation in formalin.

Color in life. Immediately after capture, specimens with overall golden body coloration and orangish to red fins. Humeral spot faint black. Midlateral stripe and caudal-peduncle spot less conspicuous than after preservation. Caudal-fin middle rays black, and median portion of lobes yellowish white.

Sexual dimorphism. Males of Astyanax courensis are easily recognized by the presence of small bony hooks on the anal-fin rays. Also, males and females differ by anal-fin shape, which is nearly straight in males and concave in females. Gill glands (Burns \& Weitzman, 1996) were not found macroscopically on first gill arch in either males or females.

Distribution. Astyanax courensis is known from the rio dos Couros basin, tributary of rio Tocantinzinho, upper rio Tocantins basin, Alto Paraíso de Goiás, Chapada dos Veadeiros, Goiás State, Brazil (Fig. 3).

Ecological notes. See features about rio dos Couros in the ecological notes above. Most of the specimens were collected on the stretch downstream from the waterfall (Fig. 4a). Also it was observed few specimens on the stretch upstream of waterfall. Only four species were collected syntopically with A. courensis: Characidium stigmosum, C. aff. zebra, Gymnotocinclus anosteos and Trichomycterus sp. Stomach contents of five specimen (UFRGS 11290) presented Plecoptera, Trichoptera, Chironomidae (Diptera), authochthonous and allochthonous insects, and digested vegetal organic matter. The stomachs were partially full.
Etymology. The specific name courensis is in reference to the type-locality, rio dos Couros, an important tributary of rio Tocantinzinho, upper rio Tocantins basin. An adjective.

\section{Discussion}

Astyanax goyanensis and A. courensis have the characters and general body morphology of the species of the $A$. scabripinnis species complex as discussed by Bertaco \& Malabarba (2001) and established and delimited by Bertaco \& Lucena $(2006,2010)$.

Astyanax goyanensis is herein recognized in Astyanax following the currently used definition of the genus proposed by Eigenmann (1927). Eigenmann (1907) distinguished Astyanacinus from Astyanax mainly by the "maxillary length more than half the length of the head" in the former, a character not found in Astyanax goyanensis (Table 1).

Due to the poor Astyanacinus goyanensis description by Miranda-Ribeiro (1944), some features were incorrectly reported. The holotype and some paratypes of Astyanacinus goyanensis lack several body scales, and the holotype's anal fin is incomplete as previously mentioned in the original description, "lateral line counts for holotype (27?), and for seven paratypes (27-31)". Despite of the lack of body scales in the type series of Astyanacinus goyanensis, the count of scales and/or marks in the lateral line revealed about 34-36, the same values found in the topotypes. The holotype of Astyanacinus goyanensis has five maxillary teeth and the maxillary length is slightly larger than half-length of head $(51.5 \%$, Table 1$)$. These features must have induced the author to describe the species as integrant of Astyanacinus instead of Astyanax. The analyzed paratypes have 2(2), 3(2), and 5(1) 
teeth at the maxilla and the maxillary length is smaller than half-length of the head (Table 1), as observed in all topotypes. At present, the lower jaw and caudal fin of the holotype (Fig. 1a) are broken, probably due to fixation/conservation and/or handling without caution, but the type specimen seemed to be on perfect conditions as shown the picture in the original description (Miranda-Ribeiro, 1944, fig. p. 3).

Astyanax goyanensis remained for almost six decades after its original description without citation or mention in any paper (except in Fowler, 1948). It was listed only recently in two check lists of freshwater fishes as Astyanacinus goyanensis by Lima et al. $(2003,2007)$, and its taxonomic characterization remains indefinite or questionable. Note that this species was not cited by Géry (1977).

All examined specimens of Astyanax goyanensis have seven pelvic-fin rays $(i, 6)$, a character uncommon in the genus, but variable in some species (i,6-7). Note that this count was not mentioned in the original description by Miranda-Ribeiro (1944). Among the Astyanax scabripinnis species complex this count can be found only in three species: $A$. brachypterygium, A. ita, and A. obscurus (see differences in the diagnosis above).

We analyzed the types and/or non type specimens of the remaining nominal species of Astyanacinus. Astyanax goyanensis differs from Astyanacinus multidens Pearson and Astyanacinus moorii Boulenger by the number of lateral line scales (35-37 vs. 39-40), the number of scale rows at the caudal peduncle (14 vs. 18), the total number of transverse scales (12-13 vs. 15-16), the number of branched anal-fin rays (13-16 vs. 25-31), pelvic-fin rays (8 vs. 7), and humeral spot horizontally elongate vs. vertically elongate. Both Astyanacinus species have the midlateral region with transverse anteriorly directed $\mathrm{V}$-shaped bars along myomere junctions, a character not found in the Astyanax species. The holotype (unique type known) of Astyanacinus platensis fits neither in the traditional definition of Astyanacinus nor Astyanax, but it has 17 maxillary teeth, 23 predorsal scales, and 20 scale rows around caudal peduncle; all these characters are not found in Astyanax and Astyanacinus, but are usually found in Oligosarcus species, another characiform genus.

The species of Astyanacinus and Astyanax are not well diagnosed, and the phylogenetic position of these genera within the characiform tree-of-life is not known. None of the characters used by Eigenmann are unique to the genera, and the actual number of valid species still remains questionable.

In addition to Astyanax goyanensis and A. courensis, only two additional species of Astyanax from the upper rio Tocantins basin have been described, A. unitaeniatus Garutti and $A$. elachylepis Bertaco \& Lucinda. The former species belong to A. bimaculatus species group (sensu Garutti, 1995), and they are clearly distinguished from $A$. goyanensis and $A$. courensis by the horizontally elongate humeral spot ( $v s$. vertically elongate), presence of two vertical dark bars in the humeral region ( $v s$. absent), the number of branched anal-fin rays (17$21 v s .13-16$ and 15-17, respectively), and total pelvic-fin rays (8 vs. 7 in A. goyanensis). Astyanax goyanensis and A. courensis differ from A. elachylepis by the number of lateral line scales (35-37 vs. 48-53) and branched anal-fin rays (13-16 and 15-17 vs. 22-27).

Recently, Garutti \& Langeani (2009) redescribed Astyanax goyacensis Eigenmann (1908) from the rio Vermelho, a tributary of the rio Araguaia that belongs to Araguaia-Tocantins basin, Goiás State, and included on Astyanax bimaculatus species group. Astyanax goyanensis differs from A. goyacensis by shape of humeral spot (vertically elongate $v s$. horizontally ovate), and by the number of branched anal-fin rays (13-16 vs. 18-24), pelvicfin rays (7vs. 8), and the number of teeth and cups of maxillary (25 tri- to pentacuspid $v s .0-1$ uni or tricuspid teeth). Although $A$. goyacensis possesses a very similar name to the species redescribed herein (A. goyanensis), this specific case of oneletter difference ("c" and " $n$ ") is not included in the ICZN (1999) list of examples that characterize cases of homonymy (Article 57, paragraph 57.6; and Article 58).

The rediscovery of Astyanax goyanensis and the description of one new species, A. courensis, support the hypothesis that the upper rio Tocantins basin possesses a highly endemic ichthyofauna (Fisch-Müller et al., 2001, 2005; Pereira \& Lucinda, 2007; Bertaco \& Carvalho, 2010), and the Tocantins-Araguaia ecoregion as a whole (sensu Abell et al., 2008), showing a high number of endemic freshwater fish species. The Chapada dos Veadeiros region inserted in the Brazilian Cerrado, is one of the world's biodiversity hotspots (Myers et al., 2000; Silva \& Bates, 2002; Klink \& Machado, 2005), sheltering endemic species in Plantae (Irwin \& Arroyo, 1973; Pastore \& Cavalcante, 2008; Pastore \& Marques, 2009), Trichoptera (Calor, 2008), Anura (Bockermann, 1975; Caramaschi $\&$ Cruz, 2000), Aves (Silva, 1997; Tubelis, 2009), and Mammalia (Bonvicino et al., 2005). The lack of recognition of endemic species leads to their exclusion/forgetfulness from lists of threatened species, and the consequent absence of efforts and funds for their conservation and of the ecoregions that harbor them. Accordingly, we assert that there should be an increasing effort to record these forgotten species to compose a more realistic scenario of the Neotropical biodiversity.

Comparative material. In addition to the comparative material listed in Bertaco \& Lucena (2006), the following specimens were analyzed: Astyanacinus moorii, BMNH 1892.4.20.50-51, 1 of 2 syntypes, $65.2 \mathrm{~mm}$ SL, "Chapala Plateau”, Mato Grosso, Brazil. MCP 37951, 3, ribeirão Figueira, rio Paraguay basin, Poconé, Mato Grosso, Brazil. MCP 15572, 5, 54.9-66.4 mm SL, tributary of rio Paraguay, Cáceres, Mato Grosso, Brazil. Astyanacinus multidens, MCP 35017, 17, 2 c\&s, 48.3-64.2 mm SL, MCP 35018, 6 of 28, 37.6-42.7 mm SL, tributary of rio Chapare, rio Madeira basin, Cochabamba, Bolivia. Astyanacinus platensis, MHNM 762, holotype, $97.0 \mathrm{~mm}$ SL, laguna Tropa Vieja, Canelones, Uruguay. Astyanax argentatus, USNM 869, 12 of 28 syntypes, 41.1-60.7 $\mathrm{mm}$ SL, río Nueces, Texas, United States. Astyanax burgerai, UFRGS 11035, 43, 18.0-35.4 mm SL, tributary of rio Una basin, Arataca, Bahia, Brazil. Astyanax mexicanus, UFRGS 9681, 15 of 50, 3 c\&s, 41.2-63.8 mm SL, rio Ojo Frio, San Luis Potosi, Mexico. USNM 310224, 14, 52.8-67.4 mm SL, Guadalupe River, United States. Astyanax varzeae, MCP 40535, 14 paratypes, 43.9-72.0 $\mathrm{mm} \mathrm{SL}$, rio da Várzea, upper rio Iguaçu basin, Tijucas do Sul, 
Paraná, Brazil. Astyanax sp., UFRGS 11200, 41, 29.8-49.4 mm SL, rio Prata at Cachoeira do Prata, UFRGS 11201, 48, 27.6-54.7 $\mathrm{mm}$ SL, stream about $14 \mathrm{~km} \mathrm{~N}$ of Cavalcante; rio Paranã basin, Cavalcante, Goiás, Brazil.

\section{Acknowledgements}

We are grateful to Renata B. Araújo and Javier MaldonadoOcampo (MNRJ) for the image of holotype and analysis of type series of Astyanacinus goyanensis; Marcelo Loureiro (MHNM) for the loan of Astyanacinus platensis; Guilherme Frainer (UFRGS) by help with collecting specimens; Andréia Turcati (UFRGS) by helping with the analysis of stomach contents; Roberto E. Reis (MCP) by analysis of types of Astyanacinus moorii; Lilian Casatti (UNESP) by assistance on map; Centro de Microscopia Eletrônica - CME, UFRGS for the SEM preparations. VAB is financed by a postdoctoral fellowship from CNPq (Proc. 150042/2009-4), andFAPERGS (Proc. 0903014). FRC and FCJ are supported by a doctoral fellowship from CNPq (Procs. 141028/2007-6 and 201513/2009-9) and CAPES, respectively. Fieldwork support was in part provided by $\mathrm{CNPq}$ (Proc. 479412/2008-1). Collecting permits were provided by Instituto Brasileiro do Meio Ambiente e dos Recursos Naturais Renováveis - IBAMA (\# 1507-1).

\section{Literature Cited}

Abell, R., M. L. Thieme, C. Revenga, M. Bryer, M. Kottelat, N. Bogutskaya, B. Coad, N. Mandrak, S. Contreras Balderas, W. Bussing, M. L. J. Stiassny, P. Skelton, G. R. Allen, P. Unmack, A. Naseka, R. Ng, N. Sindorf, J. Robertson, E. Armijo, J. V. Higgins, T. J. Heibel, E. Wikramanayake, D. Olson, H. L. López, R. E. Reis, J. G. Lundberg, M. H. Sabaj-Pérez \& P. Petry. 2008. Freshwater Ecoregions of the World: A new map of biogeographic units for freshwater biodiversity conservation. BioScience, 58(5): 403-414.

Bertaco, V. A. \& F. R. Carvalho. 2010. New species of Hasemania (Ostariophysi: Characiformes: Characidae) from Central Brazil, with comments on the endemism of upper rio Tocantins basin, Goiás State. Neotropical Ichthyology, 8(1): 27-32.

Bertaco, V. A. \& C. A. S. Lucena. 2006. Two new species of Astyanax (Ostariophysi: Characiformes: Characidae) from eastern Brazil with a synopsis of the Astyanax scabripinnis species complex. Neotropical Ichthyology, 4(1): 53-60.

Bertaco, V. A. \& C. A. S. Lucena. 2010. Redescription of the Astyanax obscurus (Hensel, 1870) and A. laticeps (Cope, 1894) (Teleostei: Characidae): two valid freshwater species originally described from rivers of Southern Brazil. Neotropical Ichthyology, 8(1): 7-20.

Bertaco, V. A. \& P. H. F. Lucinda. 2005. Astyanax elachylepis, a new characid fish from the rio Tocantins drainage, Brazil (Teleostei: Characidae). Neotropical Ichthyology, 3(3): 389-394.

Bertaco, V. A. \& L. R. Malabarba. 2001. Description of new species of Astyanax (Teleostei: Characidae) from headwater streams of Southern Brazil, with comments on the "A. scabripinnis species complex". Ichthyological Exploration of Freshwaters, 12(3): 221-234.

Bokermann, W. C. A. 1975. Uma nova espécie de Colosthetus do Brasil Central (Anura, Dendrobatidae). Iheringia (Zoologia), 46:13-19.
Bonvicino, C. R., B. Lemos \& M. Weksler. 2005. Small mammals of Chapada dos Veadeiros National Park (Cerrado of Central Brazil): ecologic, karyologic, and taxonomic considerations. Brazilian Journal of Biology, 65(3): 395-406.

Burns, J. R. \& S. H. Weitzman. 1996. Novel gill-derived gland in the male swordtail characin, Corynopoma riisei (Teleostei: Characidae: Glandulocaudinae). Copeia, 1996(3): 627-633.

Calcagnotto, D., S. A. Schaefer \& R. DeSalle. 2005. Relationships among characiform fishes inferred from analysis of nuclear and mitochondrial gene sequences. Molecular Phylogenetics and Evolution, 36(1): 135-153.

Calor, A. R. 2008. A new species of Notalina Mosely, 1936 (Trichoptera: Leptoceridae) from Chapada dos Veadeiros National Park, Goiás state, Brazil. Biota Neotropica, 8(3): 175-178.

Caramaschi, U. \& C. A. G. Cruz. 2000. Duas espécies novas de Hyla Laurenti, 1768 do estado de Goiás, Brasil (Amphibia, Anura, Hylidae). Boletim do Museu Nacional, Nova Série, Zoologia, 422: 1-12.

Eigenmann, C. H. 1907. Fowler's "Heterognathus Fishes" with a note on the Stethaprioninae. American Naturalist, 41(492): 767-772.

Eigenmann, C. H. 1921. The American Characidae. Part 3. Memoirs of the Museum of Comparative Zoology, 43: 208-310.

Eigenmann, C. H. 1927. The American Characidae. Part 4. Memoirs of the Museum of Comparative Zoology, 43: 311-428.

Eschmeyer, W. N. \& R. Fricke (Eds.). 2010. Catalog of Fishes. Electronic version - 15 Jan 2010, California Academy of Sciences. Avalaible at: http://research.calacademy.org/ichthyology/catalog/ fishcatmain.asp (February 10, 2010).

Fink, W. L. \& S. H. Weitzman. 1974. The so-called cheirodontin fishes of Central America with descriptions of two new species (Pisces: Characidae). Smithsonian Contributions to Zoology, 172: 1-46.

Fisch-Müller, S., R. Mazzoni \& C. Weber. 2001. Genetic and morphological evidences for two new sibling species of Ancistrus (Siluriformes: Loricariidae) in upper rio Tocantins drainage, Brazil. Ichthyological Exploration of Freshwaters, 12(4): 289-304.

Fisch-Müller, S., A. R. Cardoso, J. F. Pezzi da Silva \& V. A. Bertaco. 2005. Three new species of Ancistrus Kner (Teleostei: Siluriformes: Loricariidae) from the upper Tapajós and Tocantins rivers. Revue Suisse de Zoologie, 112(2): 559-572.

Fowler, H. W. 1948. Os peixes de água doce do Brasil. Arquivos de Zoologia do Estado de São Paulo (1 $1^{\mathrm{a}}$ entrega), 6: 1-204.

Garutti, V. 1995. Revisão taxonômica dos Astyanax (Pisces, Characidae), com uma mancha umeral ovalada e mancha no pedúnculo caudal, estendendo-se à extremidade dos raios caudais medianos, das bacias do Paraná, São Francisco e Amazônica. Unpublished Livre-docência thesis, Universidade Estadual Paulista, IBILCE-UNESP, São José do Rio Preto, 286p.

Garutti, V. \& F. Langeani. 2009. Redescription of Astyanax goyacensis Eigenmann, 1908 (Ostariophysi: Characiformes: Characidae). Neotropical Ichthyology, 7(3): 377-383.

Géry, J. 1977. Characoids of the World. T. F. H. Publications, Neptune City, 672p.

ICZN (International Commission on Zoological Nomenclature). 1999. International Code of Zoological Nomenclature. $4^{\text {th }}$ ed., London, 306p.

Irwin, H. S. \& M. T. K. Arroyo. 1973. New endemic species of Harpalyce (Leguminosae: Brongniartieae) from south-Central Brazil with a key to the Brazilian species. Brittonia, 25(1): 21-25. 
Javonillo, R., L. R. Malabarba, S. H. Weitzman \& J. R. Burns. 2010. Relationships among major lineages of characid fishes (Teleostei: Ostariophysi: Characiformes), based on molecular sequence data. Molecular Phylogenetics and Evolution, 54(2010): 498-511.

Lima, F. C. T., L. R. Malabarba, P. A. Buckup, J. F. Pezzi da Silva, R. P. Vari, A. Harold, R. Benine, O. T. Oyakawa, C. S. Pavanelli, N. A. Menezes, C. A. S. Lucena, M. C. S. L. Malabarba, Z. M. S. Lucena, R. E. Reis, F. Langeani, L. Casatti, V. A. Bertaco, C. Moreira \& P. H. F. Lucinda. 2003. Genera incertae sedis in Characidae. Pp. 106-169. In: R. E. Reis, S. O. Kullander \& C. J. Ferraris (Eds.). Check List of the Freshwater Fishes of South and Central America. Porto Alegre, Edipucrs, 729p.

Lima, F. C. T., P. A. Buckup, N. A. Menezes, C. A. S. Lucena, M. C. S. L. Malabarba, Z. M. S. Lucena, M. Toledo-Piza \& A. Zanata. 2007. Família Characidae: Gêneros incertae sedis. Pp. 44-62. In: P. A. Buckup, N. A. Menezes \& M. S. Ghazzi (Eds.). Catálogo das espécies de peixes de água doce do Brasil. Rio de Janeiro, Museu Nacional, 195p.

Klink, C. A. \& R. B. Machado. 2005. A conservação do Cerrado brasileiro. Megadiversidade, 1(1): 147-155.

Miranda-Ribeiro, P. 1944. Nova espécie para o gênero Astyanacinus Eigenmann, 1907 (Pisces, Characinidae). Boletim do Museu Nacional, Rio de Janeiro, 29: 1-2.

Mirande, J. M. 2009. Weighted parsimony phylogeny of the family Characidae (Teleostei: Characiformes). Cladistics, 25: 1-39.

Marinho, M. M. F. \& F. C. T. Lima. 2009. Astyanax ajuricaba: a new species from the Amazon basin in Brazil (Characiformes: Characidae). Neotropical Ichthyology, 7(2): 169-174.

Myers, N., R. A. Mittermeir, C. G. Mittermeir, G. A. B. Fonseca \& J. Kent. 2000. Biodiversity hotspots for conservation priorities. Nature, 403: 853-858.
Pastore, J. F. B. \& T. B. Cavalanti. 2008. New species of Polygala (Polygalaceae) from Brazil. Novon, 17: 90-93.

Pastore, J. F. B. \& M. C. M. Marques. 2009. Duas novas espécies de Polygala (Polygalaceae) da região da Chapada dos Veadeiros, GO, Brasil. Acta Botânica Brasilica, 23(2): 446-450.

Pereira, T. N. A. \& P. H. F. Lucinda. 2007. A new species of Jupiaba Zanata, 1997 (Ostariophysi, Characiformes, Characidae) from the rio Tocantins drainage, Brazil. Zootaxa, 1614: 53-60.

Silva, J. M. C. 1997. Endemic bird species and conservation in the cerrado region, South America. Biodiversity and Conservation, 6(4): 435-450.

Silva, J. M. C. \& J. M. Bates. 2002. Biogeographic Patterns and Conservation in the South American Cerrado: A Tropical Savanna Hotspot. BioScience, 52(3): 225-234.

Taylor, W. R. \& G. C. van Dyke. 1985. Revised procedures for staining and clearing small fishes and other vertebrates for bone and cartilage study. Cybium, 9: 107-119.

Tubelis, D. P. 2009. Veredas and their use by birds in the Cerrado, South America: a review. Biota Neotropica, 9(1): 1-12.

Vari, R. P. \& R. M. C. Castro. 2007. New species of Astyanax (Ostariophysi: Characiformes: Characidae) from the Upper Rio Paraná System, Brazil. Copeia, 2007(1): 150-162.

Weitzman, S. H. \& L. R. Malabarba. 1998. Perspectives about the phylogeny and classification of the Characidae (Teleostei: Characiformes). Pp. 161-170. In: L. R. Malabarba, R. E. Reis, R. P. Vari, Z. M. S. Lucena \& C. A. S. Lucena (Eds.). Phylogeny and Classification of Neotropical Fishes. Porto Alegre, Edipucrs, 603p.

Accepted January 25, 2010

Published June 25, 2010 